\title{
SISTEM PENDUKUNG KEPUTUSAN MENGGUNAKAN METODE FUZZY SUGENO UNTUK MENENTUKAN CALON PRESIDEN MAHASISWA DI UNIVERSITAS ASAHAN
}

\author{
Muhammad Yasin Simargolang ${ }^{1}$, Helki Saidah Tamba ${ }^{2}$ \\ ${ }^{12}$ Fakultas Teknik Jurusan Teknik Informatika Universitas Asahan \\ Jln. Jend. Ahmad Yani, Kisaran, Sumatera Utara \\ Imuhammadyasins@gmail.com, 2helkitamba@gmail.com
}

\begin{abstract}
ABSTRAK - Presiden mahasiswa merupakan pemimpin para mahasiswa yang bertujuan sebagai mediasi mahasiswa dengan pihak rektorat. Setiap tahunnya akan diadakan pemilihan presiden mahasiswa. Untuk melaksanakan pemilihan, tentunya harus memiliki kandidat sebagai calon. Untuk menjadi calon, panitia menyeleksi para kandidat berdasarkan syarat-syarat yang sudah ditentukan. Penyeleksian tersebut dilakukan secara manual. Namun, kandidat berasal dari fakultas dan jurusan yang berbeda-beda yang mengakibatkan dengan segala keterbatasannya, panitia akan kesulitan dan butuh waktu relatif lama untuk menetapkan calon. Untuk itu, membangun sebuah sistem pendukung keputusan menggunakan metode fuzzy sugeno untuk menentukan calon presiden mahasiswa itu merupakan suatu gagasan yang baik. Penelitian ini bertujuan untuk merancang dan menerapkan sistem pendukung keputusan dengan metode fuzzy sugeno, untuk mempermudah panitia dalam bekerja. Penelitian ini menggunakan metode penelitian pustaka. Dimana sumber informasi diperoleh dari buku, jurnal, dan lain-lain. Untuk merancang sistem yang dibuat menggunakan UML. Berdasarkan perancangan sistem, implementasi dan pengujian, diperoleh kesimpulan bahwa sebuah sistem pendukung keputusan dengan metode fuzzy sugeno dapat menentukan calon presiden mahasiswa. Sistem yang dibangun dapat digunakan sebagai alternatif dalam pemilihan calon presiden mahasiswa karena dapat mempermudah panitia dalam mengolah data untuk mengambil keputusan.
\end{abstract}

Kata Kunci - Calon Presiden Mahasiswa, Sistem Pendukung Keputusan, Fuzzy Sugeno

\section{PENDAHULUAN}

Organisasi Mahasiswa di Indonesia dapat dikategorikan ke dalam 2 jenis, yaitu organisasi mahasiswa internal kampus dan eksternal kampus. Organisasi mahasiswa internal kampus adalah organisasi mahasiswa yang melekat pada pribadi kampus atau universitas, dan memiliki kedudukan resmi di lingkungan perguruan tinggi. Salah satu bentuk organisasinya yaitu Presiden Mahasiswa (Presma). Dalam konteks kemahasiswaan, presiden merupakan pemimpin para mahasiswa, yang berfungsi sebagai mediasi antara mahasiswa dan pihak rektorat khususnya dalam melakukan hubungan interaksi guna keberlangsungan proses akademik yang bersifat komunikatif. Presiden mahasiswa mempunyai peran dan tanggung jawab dalam mengawasi serta mengadvokasi setiap kebijakan-kebijakan rektorat yang tidak berpihak terhadap masyarakat kampus. Presiden mahasiswa sendiri akan dipilih secara langsung oleh masyarakat kampus dari antara beberapa calon presiden mahasiswa.

Universitas Asahan merupakan sebuah instansi pendidikan tingkat lanjut yang berdiri sejak tahun 1985, yang beralamat di Jln. Jend. Ahmad Yani, Kisaran Naga, Kisaran Timur, Kab. Asahan. Setiap periodenya, Universitas Asahan ikut serta melakukan pemilihan presiden mahasiswa kampus. Sebagai sebuah wadah pendidikan, tentunya Universitas Asahan memiliki berbagai jenis fakultas dan juga jurusan. Hal inilah yang menyebabkan timbulnya masalah dalam penentuan calon presiden mahasiswa kampus, dimana mahasiswa yang mengajukan diri berasal dari berbagai jurusan dan fakultas yang berbeda dengan jumlah yang banyak.
Dalam penentuan calon presiden mahasiswa, ada tahap dimana panitia harus menelaah dan membandingkan kualitas pencalon yang satu dengan yang lain untuk menyeleksi para mahasiswa yang mengajukan diri untuk menjadi seorang calon yang akan berkesempatan untuk dipilih nanti. Hal itu dilakukan masih dengan cara manual, yang artinya semua data yang ada diolah oleh panitia dengan pikiran dan logika sendiri. Dengan segala keterbatasannya, panitia pasti kewalahan dan butuh waktu yang relatif lama untuk menetapkan calon-calon yang terbaik. Disamping permasalahan di atas, terkadang panitia dalam menentukan calon tidak memperhatikan semua kualifikasi yang dimiliki setiap pencalon, sehingga hasilnya kurang objektif. Dan terkadang timbulnya sikap memihak terhadap salah satu pencalon.

Oleh karena itu, perlu dirancang suatu sistem yang dapat mengatasi masalah tersebut. Dalam pemecahan masalah di atas, peneliti menggunakan penyelesaian dengan logika fuzzy. Untuk program penyeleksian yang akan dibuat akan menggunakan fuzzy sugeno, karena metode ini mampu mengelompokkan data berdasarkan input yang telah dipilih dan menerapkan aturan yang telah ditetapkan sehingga bisa menentukan siapa yang lebih berhak mendapat kesempatan sebagai calon presiden mahasiswa di Universitas Asahan.

Sesuai dengan latar belakang masalah yang diungkapkan di atas, maka peneliti mengangkat penelitian dengan judul "Sistem Pendukung Keputusan Menggunakan Metode Fuzzy Sugeno Untuk Menentukan Calon Presiden Mahasiswa di Universitas Asahan". 


\section{LANDASAN TEORI}

\section{A. Sistem Pendukung Keputusan}

Menurut Alter (dalam Harold Situmorang, 2015), sistem pendukung keputusan merupakan sistem informasi yang interaktif yang menyediakan informasi, pemodelan, dan pemanipulasian data. Sistem ini digunakan untuk membantu pengambilan keputusan dalam situasi yang semistruktur dan situasi yang tidak terstruktur, dimana seorang pun tahu secara pasti bagaimana keputusan seharusnya dibuat.

SPK bertujuan untuk menyediakan informasi, membimbing, memberikan prediksi serta mengarahkan kepada pengguna informasi agar dapat melakukan pengambilan keputusan dengan lebih baik. SPK merupakan implementasi teori-teori pengambilan keputusan yang telah diperkenalkan oleh ilmu-ilmu seperti operation research dan menegement science, hanya bedanya adalah bahwa jika dahulu untuk mencari penyelesaian masalah yang dihadapi harus dilakukan perhitungan iterasi secara manual (biasanya untuk mencari nilai minimum, maksimum, atau optimum), saat ini komputer telah menawarkan kemampuannya untuk menyelesaikan persoalan yang sama dalam waktu relatif singkat.

\section{B. Fuzzy}

Fuzzy adalah sebuah sistem kontrol untuk pemecahan masalah berbasis komputer berbasis akuisisi data. Logika fuzzy mempunyai dua kemungkinan seperti 0 atau 1, "benar" atau "salah". Meskipun nilai keanggotaannya sama namun fuzzy mampu membedakaan nilai dari keanggotaan tersebut dari bobot yang dimiliki. Fuzzy mampu memodelkan fungsi-fungsi non linier yang sangat kompleks dan memiliki toleransi terhadap data yang tidak tepat dengan menggunakan bahasa alami sehingga mudah untuk dimengerti (Magdalena Simanjuntak dan Achmad Fauzi, 2017).

Menurut Rizky Meimaharani (dalam Muhammad Dedi Irawan, 2017), Logika fuzzy adalah peningkatan dari logika boolean yang berhadapan dengan konsep kebenaran sebagian. Saat logika klasik menyatakan segala hal dapat didefinisikan dalam istilah biner ( 0 atau 1 , hitam atau putih, ya atau tidak), logika fuzzy menggantikan kebenaran boolean dengan tingkat kebenaran.

\section{a. Fuzzy Sugeno}

Menurut Sri Kusumadewi (dalam Fajar Rohman Hariri, 2016), logika fuzzy sugeno secara umum dimaknai sebagai suatu logika yang digunakan untuk menghasilkan keputusan tunggal/crisp saat defuzzifikasi, penggunaannya tergantung dari domain masalah yang terjadi. Dimana urutan prosesnya dimulai dari fuzzifikasi, penerapan rule, defuzzifikasi dan output.

Fuzzy sugeno pertama kali diperkenalkan oleh Takagi-Sugeno Kang pada tahun 1985. Sehingga metode ini sering dinamakan dengan metode TSK (Takagi-Sugeno Kang). Dimana logika fuzzy sugeno memiliki persamaan bentuk dengan metode fuzzy mamdani hanya berbeda pada output. Metode TSK ini terdiri dari 2 jenis yaitu:

\section{Model Fuzzy Sugeno Orde-Nol} Nol adalah:

Bentuk umum dari model fuzzy Sugeno Orde-

\section{IF $\left(X_{1}\right.$ is $\left.A_{1}\right)$ o $\left(X_{2}\right.$ is $\left.A_{2}\right)$ o...o $\left(X_{n}\right.$ is $\left.A_{n}\right)$ THEN $z=k$}

Dengan $A_{i}$ adalah himpunan fuzzy ke-i sebagai anteseden, dan $\mathrm{k}$ adalah suatu konstanta (tegas) sebagai konsekuen.

\section{Model Fuzzy Sugeno Orde-satu} Satu adalah:

Bentuk umum dari model fuzzy Sugeno Orde-

$$
\begin{gathered}
\text { IF }\left(X_{1} \text { is } A_{1}\right) \text { o }\left(X_{2} \text { is } A_{2}\right) \text { o...o }\left(X_{n} \text { is } A_{n}\right) \text { THEN } z= \\
p_{1} * x_{1}+\ldots+p_{n} * x_{n}+q
\end{gathered}
$$

Dengan $A_{i}$ adalah himpunan fuzzy ke-i sebagai anteseden, dan $p_{i}$ adalah suatu konstanta (tegas) ke-i dan $q$ juga merupakan konstanta pada konsekuen.

\section{b. Langkah-Langkah Penyelesaian Metode Fuzzy Sugeno}

Tahap-tahap yang diperlukan untuk memperoleh hasil output dari metode fuzzy Sugeno, yaitu :

1. Pembentukan himpunan fuzzy (fuzzifikasi).

2. Aplikasi fungsi implikasi.

Aturan dasar fuzzy mendefinisikan hubungan antara fungsi keanggotaan dan bentuk fungsi keanggotaan hasil. Pada metode Sugeno, output (konsekuen) sistem tidak berupa himpunan fuzzy melainkan berupa konstanta atau persamaan linier.

3. Komponen aturan (agregasi).

Apabila sistem terdiri dari beberapa aturan, maka inferensi diperoleh dari kumpulan dan korelasi antar aturan yaitu menghitung hasil dari $\sum_{r=1}^{R} \quad \alpha_{\mathrm{r}} \mathrm{Z}_{\mathrm{r}}$ dengan $R$ adalah banyaknya aturan (rule), $\alpha_{\mathrm{r}}$ adalah $\alpha$ predikat ke- $r$, dan $\mathrm{z}_{\mathrm{r}}$ adalah output pada anteseden aturan ke-r.

4. Penegasan (defuzzifikasi)

Defuzzifikasi pada metode Sugeno dilakukan dengan cara mencari nilai rata-ratanya.

$$
\mathrm{Z}=\frac{\sum_{i=1}^{n} \alpha_{\mathrm{i}} \mathbf{Z}_{\mathrm{i}}}{\sum_{i=1}^{n} \alpha_{\mathrm{i}}}
$$

Dengan $\alpha_{\mathrm{i}}$ adalah $\alpha$ predikat ke- $i$, dan $z_{i}$ adalah output pada anteseden aturan ke-i.

\section{PEMBAHASAN}

\section{A. Penentuan Semesta Pembicaraan}

Data yang digunakan dalam penelitian ini adalah data mengenai parameter-parameter yang meliputi IPK, Semester, dan Lama berorganisasi.. Untuk mempermudah proses penentuan calon presma dengan metode sugeno, yaitu dalam pembentukan himpunan kabur maka terlebih dahulu ditentukan semesta pembicaraan dari masing-masing variabel. Menentukan semesta pembicaraan dilakukan dengan 
mengurutkan data dari yang terkecil hingga yang terbesar pada masing-masing variabel. Sehingga didapatkan hasil seperti pada tabel berikut ini.

Tabel 1. Semesta Pembicaraan

\begin{tabular}{|l|l|l|}
\hline \multirow{5}{*}{ Fungsi } & $\begin{array}{l}\text { Nama } \\
\text { Variabel }\end{array}$ & $\begin{array}{l}\text { Semesta } \\
\text { Pembicara } \\
\text { an }\end{array}$ \\
\hline \multirow{5}{*}{ Input } & $\begin{array}{l}\text { Indeks } \\
\text { Prestasi } \\
\text { Kumulatif }\end{array}$ & $\begin{array}{l}{[1.68,} \\
3.95]\end{array}$ \\
\cline { 2 - 3 } & Semester & {$[4,12]$} \\
\cline { 2 - 3 } & $\begin{array}{l}\text { Lama } \\
\text { Berorganisas } \\
\text { i }\end{array}$ & {$[0,4]$} \\
\hline \multirow{2}{*}{ Output } & $\begin{array}{l}\text { Calon } \\
\text { Presma }\end{array}$ & {$[0,1]$} \\
\hline
\end{tabular}

\section{B. Pengaburan (Fuzzifikasi)}

Pengaburan yaitu proses dimana data inputan nilai yang bersifat tegas (crips input) ke dalam input kabur. Pada penelitian ini digunakan beberapa variabel yang digunakan dalam penentuan calon presiden mahasiswa dengan parameter IPK, semester dan lama berorganisasi. Pada metode sugeno, baik variabel input maupun variabel output dibagi menjadi satu atau lebih himpunan kabur. Dari setiap himpunan kabur yang terbentuk masing-masing mempunyai domain yang nilainya terdapat dalam semesta pembicaraan. Domain himpunan kabur adalah keseluruhan nilai yang diizinkan dalam semesta pembicaraan dan boleh dioperasikan dalam suatu himpunan kabur. Untuk lebih jelasnya, dapat dilihat pada tabel berikut :

Tabel 2 Domain Himpunan Kabur Variabel

\begin{tabular}{|c|c|c|c|}
\hline & Variabel & Himpunan & Domain \\
\hline \multirow{8}{*}{ Input } & \multirow{3}{*}{$\begin{array}{l}\text { Indeks } \\
\text { Prestasi } \\
\text { Kumulatif } \\
\text { (IPK) }\end{array}$} & Rendah & $\begin{array}{c}{[1.68-} \\
2.82]\end{array}$ \\
\hline & & Sedang & $\begin{array}{c}{[2.25-} \\
3.39]\end{array}$ \\
\hline & & Tinggi & $\begin{array}{c}{[2.82-} \\
3.95]\end{array}$ \\
\hline & \multirow{3}{*}{ Semester } & Kurang & {$[4-8]$} \\
\hline & & Cukup & {$[6-10]$} \\
\hline & & Lebih & {$[8-12]$} \\
\hline & \multirow{2}{*}{$\begin{array}{c}\text { Lama } \\
\text { Berorganisasi }\end{array}$} & Baru & {$[0-2]$} \\
\hline & & Sedang & {$[1-3]$} \\
\hline Input & $\begin{array}{c}\text { Lama } \\
\text { Berorganisasi }\end{array}$ & Lama & {$[2-4]$} \\
\hline \multirow[t]{2}{*}{ Output } & \multirow{2}{*}{$\begin{array}{l}\text { Calon } \\
\text { Presma }\end{array}$} & $\begin{array}{l}\text { Tidak } \\
\text { Lulus }\end{array}$ & {$[0]$} \\
\hline & & Lulus & [1] \\
\hline
\end{tabular}

a. Pembentukan Fungsi Keanggotaan

Setelah pembentukan himpunan kabur, langkah selanjutnya adalah pembentukan fungsi keanggotaan. Fungsi keanggotaan merupakan titik input data dalam himpunan kabur ke dalam nilai atau derajat keanggotaannya yang memiliki interval dari 0 hingga 1. Pada penelitian ini, fungsi keanggotaan didapatkan melalui pendekatan fungsi. Fungsi yang digunakan pada penelitian ini yaitu melalui representasi bentuk trapesium dan bentuk segitiga.

i. Variabel Indeks Prestasi Kumulatif (IPK)

Berdasarkan tabel 2 di atas, variabel Indeks Prestasi Kumulatif (IPK) terbagi menjadi tiga himpunan kabur, yaitu himpunan kabur rendah, sedang, tinggi. Untuk merepresentasikan IPK rendah digunakan kurva berbentuk bahu kiri, IPK sedang menggunakan kurva bentuk segitiga, dan IPK tinggi menggunakan representasi kurva berbentuk bahu kanan. Gambar himpunan kabur untuk variabel Indeks Prestasi Kumulatif (IPK) ditunjukkan pada gambar berikut :

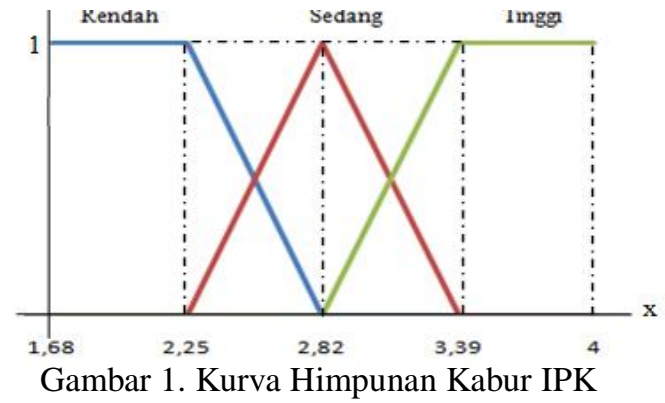

Sumbu $x$ merupakan nilai input untuk variabel Indeks Prestasi Kumulatif (IPK), sedangkan sumbu $\mu(x)$ merupakan nilai derajat keanggotaan dari nilai input. Dari gambar di atas diperoleh fungsi keanggotaannya :

$$
\begin{aligned}
& \mu_{\text {Rendah }}[x]=\left\{\begin{array}{c}
1 ; x \leq 2.25 \\
\frac{2.82-x}{0.57} ; 2.25 \leq x \leq 2.82 \\
0 ; x \geq 2.82
\end{array}\right. \\
& \mu_{\text {Sedang }}[x]=\left\{\begin{array}{c}
\frac{x-2.25}{0.57} ; 2.25 \leq x \leq 2.82 \\
\frac{3.39-x}{0.57} ; 2.82 \leq x \leq 3.39 \\
0 ; x \leq 2.25 \text { or } x \geq 3.39
\end{array}\right. \\
& \mu_{\text {Tinggi }}[x]=\left\{\begin{array}{r}
\frac{x-2.82}{0.57} ; 2.82 \leq x \leq 3.39 \\
0 ; x \leq 2.82
\end{array}\right.
\end{aligned}
$$

\section{ii. Variabel Semester}

Berdasarkan tabel 2 di atas, variabel semester terbagi menjadi tiga himpunan kabur, yaitu himpunan kabur kurang, cukup, lebih. Untuk merepresentasikan semester kurang digunakan kurva berbentuk bahu kiri, semester cukup menggunakan kurva bentuk bahu trapesium, dan semester lebih menggunakan representasi kurva berbentuk bahu kanan. Gambar himpunan kabur untuk variabel semester ditunjukkan pada gambar berikut : 


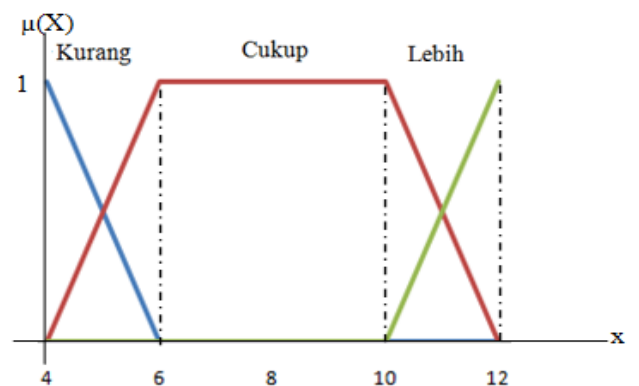

Gambar 2. Kurva Himpunan Kabur Semester

Dari gambar di atas diperoleh fungsi keanggotaannya :

$$
\begin{gathered}
\mu_{\text {Kurang }}[x]=\left\{\begin{array}{c}
1 ; x<6 \\
\frac{6-x}{2} ; 4 \leq x<6 \\
0 ; x \geq 6
\end{array}\right. \\
\mu_{\text {Cukup }}[x]=\left\{\begin{array}{c}
1 ; 6 \leq x \leq 10 \\
\frac{x-4}{2} ; 4 \leq x \leq 6 \\
\frac{12-x}{2} ; 10 \leq x \leq 12 \\
0 ; x \geq 10 \text { or } x \leq 4
\end{array}\right. \\
\mu_{\text {Lebih }[}[x]=\left\{\begin{array}{c}
\frac{x-10}{2} ; 10<x \leq 12 \\
0 ; x \leq 10
\end{array}\right.
\end{gathered}
$$

iii. Variabel Lama Berorganisasi

Berdasarkan tabel 2 di atas, variabel lama berorgaisasi terbagi menjadi tiga himpunan kabur, yaitu himpunan kabur baru, sedang, dan lama. Untuk merepresentasikan lama berorgaisasi baru digunakan kurva berbentuk bahu kiri, lama berorgaisasi sedang menggunakan kurva bentuk bahu segitiga, dan lama berorgaisasi lama menggunakan representasi kurva berbentuk bahu kanan.

Gambar himpunan kabur untuk variabel lama berorgaisasi ditunjukkan pada gambar berikut :

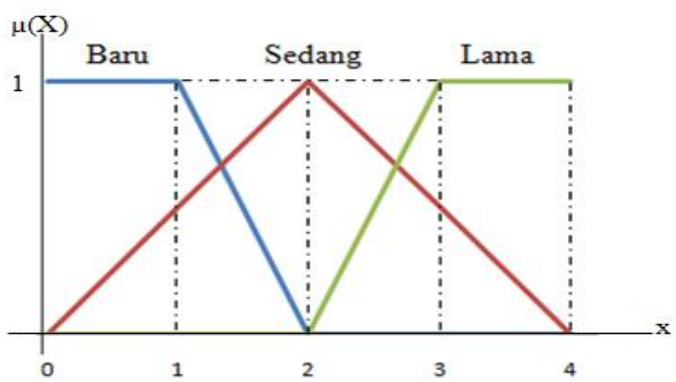

Gambar 3. Kurva Himpunan Kabur Variabel Lama Berorganisasi

Dari gambar di atas diperoleh fungsi keanggotaannya :

$$
\begin{gathered}
\mu_{\text {Baru }}[x]=\left\{\begin{array}{c}
1 ; x \leq 1 \\
\frac{2-x}{1} ; 1 \leq x \leq 2 \\
0 ; x \geq 2
\end{array}\right. \\
\mu_{\text {Sedang }}[x]=\left\{\begin{array}{c}
\frac{x-0}{1} ; 1 \leq x \leq 2 \\
\frac{4-x}{1} ; 2 \leq x \leq 3 \\
0 ; x=1 \text { or } x \geq 4
\end{array}\right. \\
\mu_{\text {Lama }}[x]=\left\{\begin{array}{c}
1 ; x \geq 3 \\
\frac{x-2}{1} ; 2 \leq x \leq 4 \\
0 ; x \leq 2
\end{array}\right.
\end{gathered}
$$

\begin{tabular}{|c|c|c|c|c|c|c|c|c|}
\hline No & & IPK & & Sem. & & $\begin{array}{c}\text { Lama } \\
\text { Org. }\end{array}$ & & $\begin{array}{c}\text { Calon } \\
\text { Presma }\end{array}$ \\
\hline 1. & IF & Rendah & AND & Kurang & AND & Baru & THEN & Tidak Lulus \\
\hline 2. & IF & Rendah & AND & Kurang & AND & Sedang & THEN & Tidak Lulus \\
\hline 3. & IF & Rendah & AND & Kurang & AND & Lama & THEN & Tidak Lulus \\
\hline 4. & IF & Rendah & AND & Cukup & AND & Baru & THEN & Tidak Lulus \\
\hline 5. & IF & Rendah & AND & Cukup & AND & Sedang & THEN & Tidak Lulus \\
\hline 6. & IF & Rendah & AND & Cukup & AND & Lama & THEN & Lulus \\
\hline 7. & IF & Rendah & AND & Lebih & AND & Baru & THEN & Tidak Lulus \\
\hline 8. & IF & Rendah & AND & Lebih & AND & Sedang & THEN & Tidak Lulus \\
\hline 9. & IF & Rendah & AND & Lebih & AND & Lama & THEN & Tidak Lulus \\
\hline 10. & IF & Sedang & AND & Kurang & AND & Baru & THEN & Tidak Lulus \\
\hline 11. & IF & Sedang & AND & Kurang & AND & Sedang & THEN & Tidak Lulus \\
\hline 12. & IF & Sedang & AND & Kurang & AND & Lama & THEN & Tidak Lulus \\
\hline 13. & IF & Sedang & AND & Cukup & AND & Baru & THEN & Lulus \\
\hline 14. & IF & Sedang & AND & Cukup & AND & Sedang & THEN & Lulus \\
\hline 15. & IF & Sedang & AND & Cukup & AND & Lama & THEN & Lulus \\
\hline 16. & IF & Sedang & AND & Lebih & AND & Baru & THEN & Tidak Lulus \\
\hline 17. & IF & Sedang & AND & Lebih & AND & Sedang & THEN & Tidak Lulus \\
\hline 18. & IF & Sedang & AND & Lebih & AND & Lama & THEN & Tidak Lulus \\
\hline 19. & IF & Tinggi & AND & Kurang & AND & Baru & THEN & Tidak Lulus \\
\hline 20. & IF & Tinggi & AND & Kurang & AND & Sedang & THEN & Tidak Lulus \\
\hline 21. & IF & Tinggi & AND & Kurang & AND & Lama & THEN & Tidak Lulus \\
\hline 22. & IF & Tinggi & AND & Cukup & AND & Baru & THEN & Lulus \\
\hline 23. & IF & Tinggi & AND & Cukup & AND & Sedang & THEN & Lulus \\
\hline 24. & IF & Tinggi & AND & Cukup & AND & Lama & THEN & Lulus \\
\hline 25. & IF & Tinggi & AND & Lebih & AND & Baru & THEN & Tidak Lulus \\
\hline 26. & IF & Tinggi & AND & Lebih & AND & Sedang & THEN & Tidak Lulus \\
\hline 27. & IF & Tinggi & AND & Lebih & AND & Lama & THEN & Tidak Lulus \\
\hline
\end{tabular}

b. Pembentukan Rule

Semua kemungkinan aturan yang dihasilkan seperti dibawah ini:

Tabel 3. Semua Kemungkinan Aturan Kabur 
c. Kasus Penerapan Sistem Pendukung Keputusan Menggunakan Metode Sugeno Untuk Menentukan Calon Presma

Seorang Mahasiswa dengan IPK 3.58, semester 6 dan lama berorganisasi 2, mendaftarkan diri untuk menjadi calon presma, maka panitia pelaksanan akan melakukan uji seleksi untuk mengetahui tingkat kelulusannya.

\section{Langkah 1. Menentukan Himpunan Kabur}

Untuk variabel IPK didefenisiskan pada tiga himpunan kabur yaitu : rendah, sedang, dan tinggi. Indeks prestasi kumulatif sebesar 3,58 termasuk ke dalam himunan kabur tinggi dengan tingkat keanggotaan sesuai fungsi, sehingga diperoleh sebagai berikut:

$$
\mu_{\text {Tingi }}[x]=\left\{\begin{array}{c}
1 ; x \geq 3.39 \\
\frac{x-2.82}{0.57} ; 2.82 \leq x \leq 3.39 \\
0 ; x \leq 2.82
\end{array}\right.
$$

Sehingga diperoleh :

$$
\begin{aligned}
& \mu_{\text {Rendah }}[3.58]=0 \\
& \mu_{\text {Sedang }}[3.58]=0 \\
& \mu_{\text {Tinggi }}[3.58]=1
\end{aligned}
$$

Yang berarti bahwa, IPK mahasiswa tersebut dapat dikatakan tinggi dengan derajat keanggotaan 1.

Untuk variabel semester didefenisikan pada tiga himpunan kabur yaitu: kurang, cukup dan lebih. Semester 6 termasuk ke dalam himpunan kabur cukup dan kurang dengan tingkat keanggotaan sesuai fungsi keanggotaan, maka diperoleh sebagai berikut :

$$
\mu_{\text {Cukup }}[x]=\left\{\begin{array}{c}
1 ; 6 \leq x \leq 10 \\
\frac{x-4}{2} ; 4 \leq x \leq 6 \\
\frac{12-x}{2} ; 10 \leq x \leq 12 \\
0 ; x \geq 10 \text { or } x \leq 4
\end{array}\right.
$$

Sehingga diperoleh :

$$
\begin{gathered}
\mu_{\text {Kurang }}[6]=0 \\
\mu_{\text {Cukup }}[6]=1 \\
\mu_{\text {Lebih }}[6]=0
\end{gathered}
$$

Yang berarti bahwa, semester mahasiswa tersebut dapat dikatakan cukup dengan derajat keanggotaan 1 .

Untuk variabel lama berorganisasi didefenisikan pada tiga himpunan kabur yaitu: baru, sedang, dan lama. Lama berorganisasi sebanyak 2 termasuk ke dalam himpunan kabur sedang dengan tingkat keanggotaan sesuai fungsi keanggotaan, maka diperoleh sebagai berikut :

$$
\mu_{\text {Sedang }}[x]=\left\{\begin{array}{c}
1 ; x=2 \\
\frac{x-1}{1} ; 1 \leq x \leq 2 \\
\frac{3-x}{1} ; 2 \leq x \leq 3 \\
0 ; x \leq 1 \text { or } x \geq 3
\end{array}\right.
$$

Sehingga diperoleh:

$$
\begin{aligned}
& \mu_{\text {sedikit }}[2]=0 \\
& \mu_{\text {sedang }}[2]=1 \\
& \mu_{\text {banyak }}[2]=0
\end{aligned}
$$

Yang berarti bahwa, lama berorganisasi mahasiswa tersebut dapat dikatakan sedang dengan derajat keanggotaan 1 .

\section{Langkah 2. Penerapan Kedalam Rule}

Fungsi implikasi yang digunakan dalam proses ini adalah fungsi MIN (minimum), yaitu dengan mengambil derajat keanggotaan yang minimum dari variabel input sebagai outputnya. Berikut penerapannya ke dalam rule yang ada.

[R1] Jika IP rendah dan SEMESTER kurang dan LAMA BERORGANISASI sedikit, Maka PESERTA tidak lulus.

$\alpha$-predikat ${ }_{1}=\mu_{\text {ip_Rend }_{-}} \cap \mu_{\text {Semester_Kurang }} \cap \mu_{\text {lama }}$

$$
\begin{aligned}
& \text { org_Baru } \\
& =\mathrm{MIN}\left(\mu_{\text {ip_Renda }} \cap \mu_{\text {Semester_Kurang }}\right. \\
& \left.\cap \mu_{\text {lama org_Baru }}\right) \\
& =\operatorname{MIN}(0,0,0) \\
& =0
\end{aligned}
$$

[R23] Jika IP tinggi dan SEMESTER cukup dan LAMA BERORGANISASI sedang, Maka PESERTA lulus.

$$
\begin{gathered}
\alpha-\text { predikat }_{23}=\mu_{\text {ip_Tinggi }_{\text {Tin }}} \cap \mu_{\text {Semester_Cukup }} \cap \mu_{\text {lama }} \\
\text { org_Sedang } \\
=\mathrm{MIN}\left(\mu_{\text {ip_Tinggi }} \cap \mu_{\text {Semester_Cukup }}\right. \\
\left.\cap \mu_{\text {lama org_Sedang }}\right) \\
=\operatorname{MIN}(1,1,1)=1
\end{gathered}
$$

\section{Langkah 3. Penegasan (Defuzzifikasi)}

Pada metode sugeno terdapat beberapa metode penegasan. Dalam menyelesaikan penelitian ini, penulis menggunakan penegasan WA (Weight Average) dengan persamaan :

Maka diperoleh :

$$
\mathbf{W A}=\frac{\sum_{i=1}^{n} \alpha i z i}{\sum_{i=1}^{n} \alpha i}
$$

$$
\mathrm{WA}=\frac{0(1)+1(1)}{0+1}=1
$$

Jadi, dengan menggunakan metode sugeno, mahasiswa yang mendaftarkan diri dengan nilai IPK sebesar 3.58, semester 6 dan lama berorganisasi 2, mempunyai tingkat kelulusan 1 dengan variabel linguistiknya adalah LULUS.

\section{d. Implementasi Tampilan Program}

1. Tampilan Halaman Pertama

Tampilan halaman pertama merupakan menu yang akan tampil setelah aplikasi di jalankan. Gambar berikut ini tampilan halaman pertama.

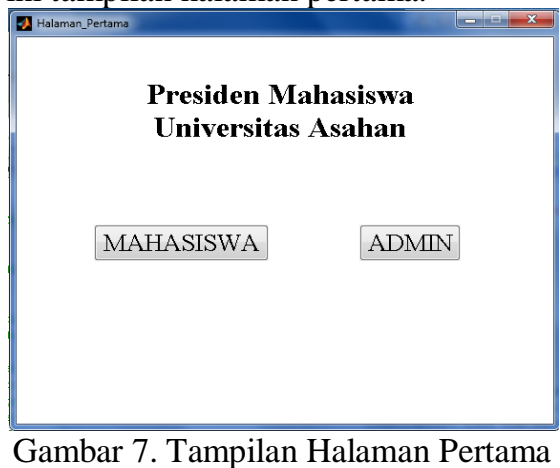




\section{Tampilan Tampilan Awal}

Tampilan awal merupakan menu yang akan tampil setelah pengguna masuk sebagai admin. Gambar berikut ini tampilan dari tampilan awal.

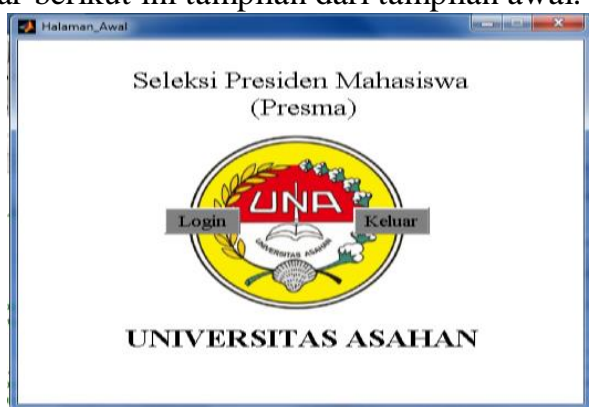

Gambar 8. Tampilan Awal

\section{Tampilan Login}

Menu login pengguna/admin merupakan menu yang akan tampil setelah tampilan awal. Gambar berikut ini tampilan dari menu login.

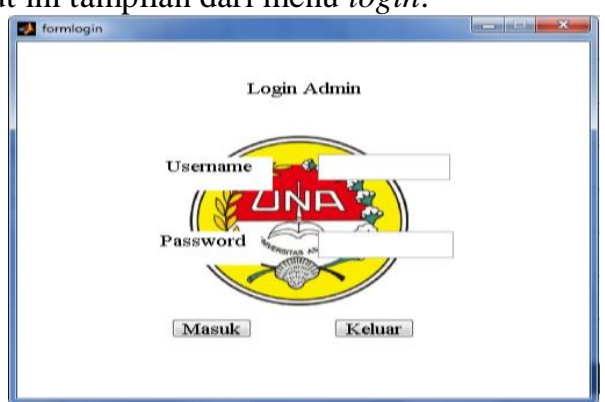

Gambar 9. Tampilan Login

4. Tampilan Beranda

Beranda merupakan menu yang akan tampil setelah login berhasil. Gambar berikut ini tampilan dari beranda.

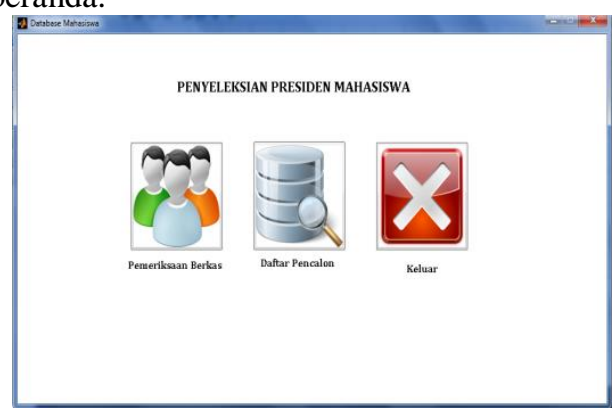

Gambar 10. Tampilan Beranda

\section{Tampilan Pemeriksaan Berkas}

Pemeriksaan berkas merupakan menu yang akan tampil ketika pengguna ingin melakukan pemeriksaan berkas. Gambar berikut ini tampilan dari pemeriksaan berkas.

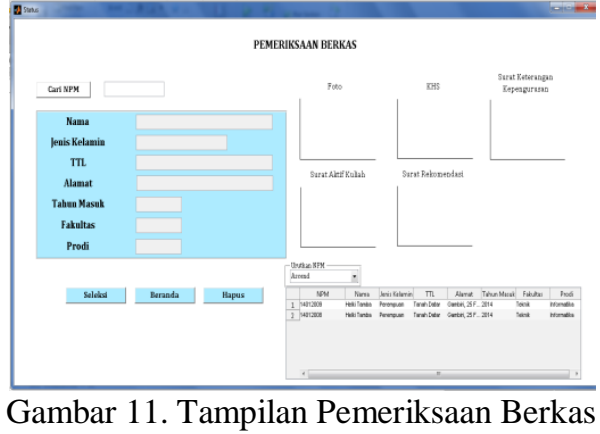

6. Tampilan Seleksi

Seleksi merupakan menu yang akan tampil setelah pengguna selesai memeriksa data. Didalam menu inilah terjadi pengolahan data. Gambar berikut ini tampilan dari seleksi.

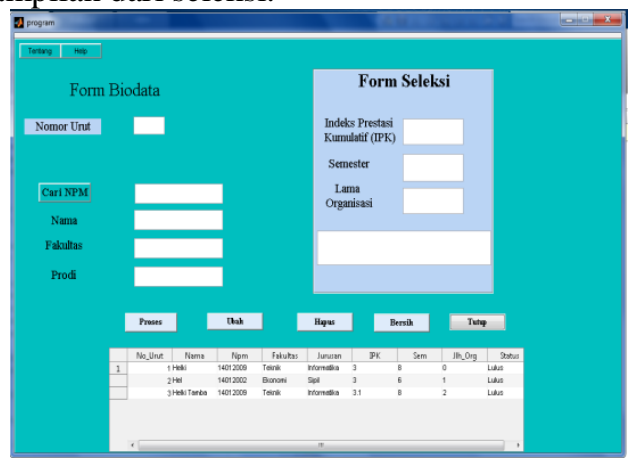

Gambar 12. Tampilan Seleksi

7. Tampilan Registrasi

Registrasi merupakan menu yang akan tampil ketika pengguna sebagai mahasiswa pada halaman pertama. Di dalam halaman ini mahasiswa yang ingin mencalonkan diri melakukan pendaftaran terlebih dahulu. Gambar berikut ini tampilan dari registrasi.

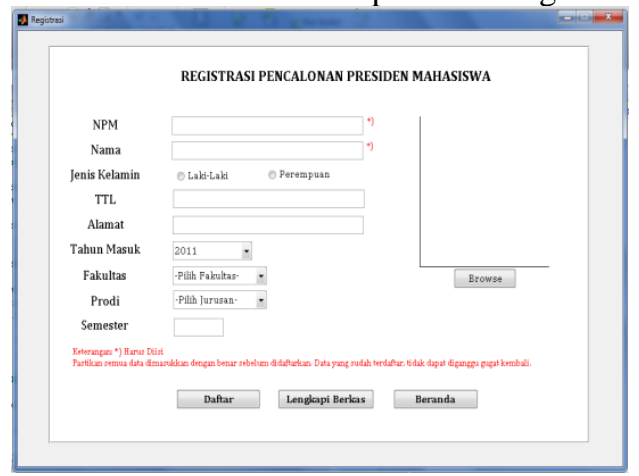

Gambar 13. Tampilan Registrasi

8. Tampilan Berkas

Berkas merupakan menu yang akan tampil ketika pengguna ingin melengkapi berkasnya. Gambar berikut ini tampilan dari berkas. 


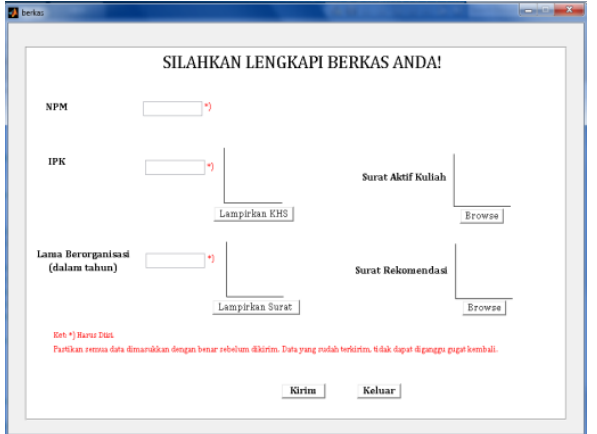

Gambar 14. Tampilan Berkas

\section{KESIMPULAN DAN SARAN}

\section{A. Kesimpulan}

Berdasarkan perancangan sistem, implementasi dan pengujian, dapat diambil kesimpulan bahwa metode fuzzy sugeno dapat diimplementasikan pada sebuah sistem pendukung keputusan untuk menentukan calon presiden mahasiswa dengan menggunakan kriteria berupa IPK, semester, dan lama organisasi. Setelah dilakukan pengisian data dari kriteria tersebut maka akan menghasilkan status kandidat tersebut apakah berhak menjadi calon presiden atau tidak. Sistem ini dapat digunakan sebagai alternatif dalam memilih calon presma, karena hasilnya yang fleksibel dalam membantu para panitia untuk mengolah data yang ada.

\section{B. Saran}

Penelitian yang dilakukan tidak terlepas dari banyaknya kekurangan dan kelemahan. Oleh karena itu, untuk pengembangan sistem lebih lanjut, maka perlu diperhatikan beberapa hal, yaitu:

1. Antarmuka dari sistem yang dibangun masih tampak sangat sederhana, sehingga dapat dikembangkan lebih menarik lagi agar pengguna merasa lebih nyaman dalam pengoperasian sistem tersebut.

2. Sistem yang dibangun diharapkan dapat dijadikan sebagai bahan dalam pengembangan dan penelitian lebih lanjut, sehingga mampu menghasilkan suatu sistem baru yang jauh lebih baik dari sistem yang dibuat ini.

3. Untuk penelitian selanjutnya diharapkan dapat menambahkan kriteria agar hasil lebih akurat.

\section{DAFTAR PUSTAKA}

[1] Ami Hilda Agustin, G.K. Gandhiadhi dan Tjokorda Bagus Oka, 2016. "Penerapan Metode Fuzzy Sugeno untuk Menentukan Harga Jual Sepeda Motor Bekas". E-Jurnal Matematika, Vol. 5 No. 4 Hal. 176-182.

[2] Fajar Rohman Hariri, 2016. "Penerapan Metode Fuzzy Sugeno Dalam Pendaftaran Siswa Baru di SDN Sonopatik 1 Nganjuk". Nusantara of Enginering, Vol.3 No.1 Hal 41-46, ISSN: 23556684.
[3] Harold Situmorang, 2015. "Sistem Pendukung Keputusan Pemilihan Calon Peserta Olimpiade Sains Tingkat Kabupaten Langkat Pada Madrasah Aliyah Negeri (Man) 2 Tanjung Pura Dengan Menggunakan Metode Simple Additive Weighting (Saw)". Jurnal TIMES, Vol. IV No. 2 Hal. 24-30, ISSN : $2337-3601$.

[4] Magdalena Simanjuntak dan Achmad Fauzi, 2017. "Penerapan Fuzzy Mamdani Pada Penilaian Kinerja Dosen (Studi Kasus STMIK Kaputama Binjai)". Jurnal ISD, Vol. 2 No. 2 Hal 143-149, p-ISSN : 2477-863X dan e-ISSN: 25285114.

[5] Muhammad Dedi Irawan, 2017. "Sistem Pendukung Keputusan Menentukan Matakuliah Pilihan pada Kurikulum Berbasis KKNI Menggunakan Metode Fuzzy Sugeno". Jurnal Media Infotama, Vol. 13 No. 1 Hal 27-35.

[6] Yongky Dwi Guritno, Indah Fitri Astuti, dan Addy Suyatno, 2017. "Sistem Pendukung Keputusan Penentuan Supplier Bahan Baku Katering $C v$. Riyanisa Sekarsari Mandiri Menggunakan Metode Fuzzy Tsukamoto". Prosiding Seminar Nasional Ilmu Komputer dan Teknologi Informasi, Vol. 2 No. 2 Hal 22-26, eISSN 2540-7902 dan p-ISSN 2541-366X. 